\title{
輸送系のXenopus 卵母細胞での発現
}

\section{山口大学教養部化学教室 青 島}

Xenopus oocytes were injected with exogenous mRNA prepared from rat small intestine and kidney and their electrical responses to glucose and amino acids were measured electrophysiologically. $\mathrm{Na}^{+} / \mathrm{glucose}$, amino acid cotransporters were expressed in the oocytes by injection of small intestine mRNA, while facilitated diffusion carrier protein(s) (uniporter) were mainly expressed by injection of kindney mRNA.

cotransporter / facilitated diffusion carrier / translation of exogenous mRNA / Xenopus oocyte

\section{1.はじめに}

アフリカッメガエル卵母細胞は, 外来の mRNA の 良い翻訳系として知られている゙。この系は, 非細胞 系では不可能な翻訳後の修飾を行い，機能を持った蛋 白質を直径 $1 \mathrm{~mm}$ 以上の球形の単細胞に発現させる゙”。 従って，不安定で小さく複雑な形をした神経細胞では むつかしい電気生理学的測定も，卵母細胞では容易に なる゙゙.すでに多数の神経伝達物質受容体やチャネル が発現され，同一の卵母細胞を用いて種々の薬物に对 する応答が様々な条件下, 繰返し長時間に渡って測定 され，受容体やチャネルの機能の研究が進められてい $ろ^{(1) .5)}$. 卵母細胞は大きいため, 薬物の注入が可能と なり, 細胞内情報伝達物質のからんだ受容体の作用機 構の研究にも大変便利である゙。図 1 に実験操作をま とめて示した.

最近,この発現系はcDNAのスクリーニングの手 段としても用いられ，蛋白質の精製が不可能な程存在 量の少ない受容体もクローニングされている゙。また， クローニングした cDNA から mRNA を合成し卵母細 胞に注入し，その cDNA が受容体に対応するもので あることか確認されている，さらには，部位特異的変 異と組み合わせて, 受容体の作用機構の研究に大変有 力な手法となっている ${ }^{\mathrm{g})}$. 従って, 卵母細胞での発現 と活性測定法の確立は，蛋白質の精製と同様，蛋白質 研究の第一歩とも言える重要性を持っている.

細胞は必要な物質を撷取し，不要物を排出するため に，生体膜に数種類の輸送体蛋白質を持っている゙”。

Expression of Transporters in Xenopus Oocytes Hitoshi AOSHIMA

Department of Chemistry, Faculty of Liberal Arts, Yamaguchi University

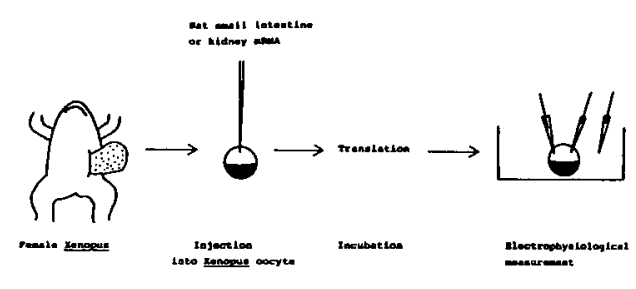

図 1 実験操作

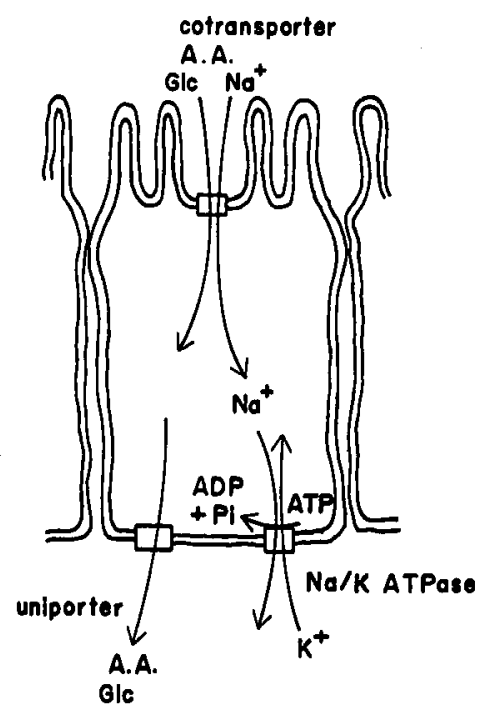

図 2 グルコース（Glc）やアミノ酸（A.A.）の上皮細 胞での輸送モデル

例えば糖やアミノ酸などの栄養物を吸収する小腸や腎 陚の上皮細胞においては，図 2 に示すような輸送系の 存在が知られている.すなわち， $\mathrm{Na}^{+} ゃ \mathrm{H}^{+}$の濃度勾 配を利用して物質を上皮細胞に取り込み（共輸送）， それを物質の濃度勾配に従って血液中に輸送（促通搪 散輸送）している. 
私達は, 小腸や腎臓の mRNAをアフリカッメガエ ル卵母細胞に注入し，糖やアミノ酸に対する細胞膜の 電気的応答を測定した．輸送体蛋白質の卵母細胞での 発現については，すでにPassow グループが，マウス の脾臓の mRNA 注入による $\mathrm{Cl}^{-}$の輸送系（バンド 3 蛋白質) の発現を, ${ }^{36} \mathrm{Cl}^{-}$の取り込みや抗体を用いて 確認している ${ }^{101}$.

\section{2．小陶 mRNA 注入による糖輸送系の発現}

ラット小腸からグアニジンチオシアネート $/ \mathrm{CsCl}$ 法オリゴ (dT) セルロースカラムによって調製し たポリ $(\mathrm{A})+\mathrm{RNA}$ を卵母細胞に注入した． 2 日間 $20^{\circ} \mathrm{C}$ で恒温槽に放置した後，グルコース（Glc）やフルク トース（Fru）に対する電気的応答をカレントクラン ブ法で測定し，図3に示した，卵母細胞に二本の電極 を刺して，一本の電極からは 5 秒ごとに図の下に示し た大きさの内向き電流を流し，他の電極で膜電位を測 定した”。従って，図に示された過分極の大きさは， 膜抵抗の大きさに比例する。

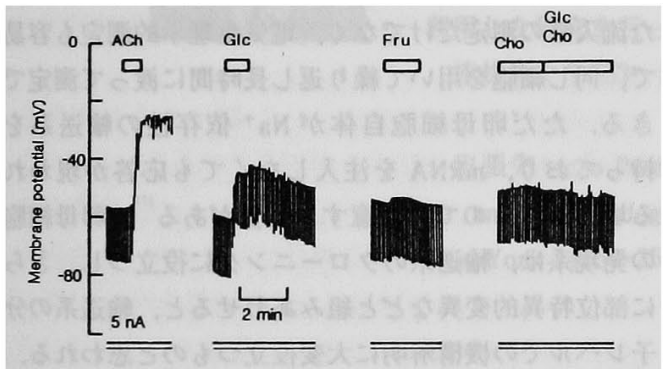

図3 小腸 mRNA を注入した卵母細胞の Ach, Glc，Fru に対する応答. choは, $\mathrm{Na}^{+}$をリン+に置換し たリンガー液。

すでに私達は，小腸 mRNAの注入によりアセチル コリン (Ach)，セロトニトン，サブスタンス P受容 体の発現に成功している 激に脱分極が起こり膜抵抗が減少することを見出した。 リンガー液に戻すと，数分かかって元の状態に戻った． この応答は，Fruに対しては起こらず，またリンガー 液の $\mathrm{Na}^{+}$をリン+に置換すると Glc に対しても応答 は失なわれた，応答の GIc 濃度依存性や $\mathrm{Na}^{+}$濃度依 存性は, 高濃度では飽和し Michaelis-Menten 型を示 した ${ }^{13)}$ 。これらの性質は，小腸やその膜ベシクルを用 いた $\mathrm{Na}^{+} / \mathrm{Glc}$ 共輸送系の実験結果と一致する. 従っ て, 小腸 mRNA を注入した卵母細胞での電気的応答 は， $\mathrm{Na}^{+}$の濃度勾配を利用した Glc の共輸送体の発現
によるものと考えられる

一方，Wright グループは， ${ }^{14} \mathrm{C} て ゙$ 標識した Glc 誘導 体の卵母細胞への取り込み量が，ウサギ小腸の約 2300 塩基の mRNA を注入すると増加することを見出し $た^{141}$ 。この mRNAを用いて cDNAを調製し，卵母細 胞の発現系を用いて cDNAのスクリーニングを行な い, Glc 共輸送系のクローニングに成功している この蛋白質は，すでにクローニングされている赤血球 膜の Glc 促通輸送蛋白質とは，全く異なるものであっ た. 部位特異的変異など分子生物学的手法と卵母細胞 発現系とも組みあわせて, Glc, $\mathrm{Na}^{+}$の結合部位など が明らかとなり，共輸送機構が分子レベルで解明され るだろう.

\section{3. 小腸 mRNA を注入した卵母細胞の アミノ酸に対する応答}

小腸の mRNA を注入したイモりやアフリカツメガ エル卵母細胞は; 種々のアミノ酸に対して図 4 に示す ような応答をした ${ }^{16)}$ ，酸性アミノ酸やCysに対する応 答は見られず，また，L-Alaには応答したが，D-Ala や $\beta$-Ala には応答せず選択性があることがわかっった。 mRNA を注入しなくても，卵母細胞は時々それ自

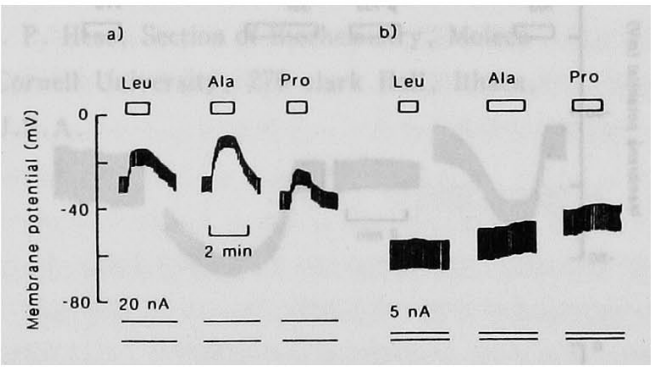

图4小腸 mRNAを注入した時(a)しない時(b)のイモリ 卵母細胞のアミノ酸に対する応答

体の持つ輸送系に由来する電気的応答を示すことがあ

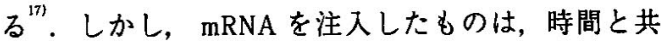
に応答が著しく増大することから，応答の大部分は小 腸の mRNA 注入による輸送系の発現によるものと考 えられる，応答電流は膜電位に直線的に依存し，逆転 電位は $0 \mathrm{mV}$ と推定された。応答は，5,5-ジチオビス (2-ニトロベンゾエイト)（MBTA）などの SH 修飾 試薬によって阻害された $。$ 。れらの性質は，小腸に 数種類存在する $\mathrm{Na}^{+}$依存性アミノ酸共輸送体の性質 と一致する。 


\section{4. 腎㖶の mRNAを注入した卵母細胞の アミノ酸に対する応答}

ラット腎葴の mRNA を卵母細胞に注入し，種々の アミノ酸に対する応答を測定したところ，驚いたこと には，過分極を引き起こすアミノ酸が見出された。 様々な応答の例を図 5 に示した。これらの応答は， $\mathrm{Na}^{+}$をリン+に置換しても失われなかった. mRNA を注入しない卵母細胞には過分極応答は全く見られず， 注入後応答か時間と共に増大することから、これらの 応答は，腎荿 mRNA 注入により発現した蛋白質によ るものと考えられる゙。.

種々のアミノ酸に対する応答を詳しく検討したとこ ろ，応答の方（脱分極か過分極か）は，アミノ酸の 等電点によって決まることがわかった．等電点がリン ガー液の $\mathrm{pH} 7.2$ 上り低い場合には過分極を，高い場合 には脱分極を示した．これは，負の電荷を持ったアミ ノ酸が流入すると過分極を，正の電荷を持ったアミノ 酸が流入すると脱分極を示すものと思われる. 実際, 過分極を示す Ala のカルボキシル基をエステル化す ると脱分極応答になること, リンガー液の $\mathrm{pH}$ を 6.0

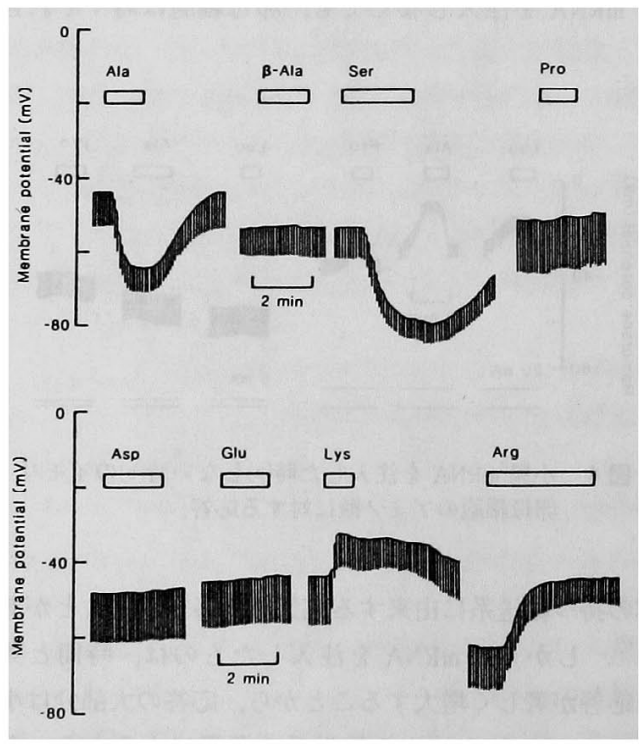

図 5 腎䑏 mRNA を注入した卵母細胞のアミノ酸に対 する応答

から8.3に上げると His（等電点7.6）の応答は，脱分 極から過分極応答に変わることが見出された. Ala 及 びLysによって引き起こされる電流の電位依存性を 検討したところ $(-90 か ら-30 \mathrm{mV})$, 直線的に変化し, 逆転電位はそれぞれー132mV，19mV と推定された。
酸性アミノ酸に対しては応答が見られず選択性を持つ こと, 濃度応答曲線は高濃度で飽和を示す Michaelis-Menten 型になることなどから, 卵母細胞に 単に穴があいたわけではなく，輸送系蛋白質による応 答と考えられる.すなわち，腎臟の mRNA を注入し た場合，主に発現するのは，促通搪散輸送体蛋白質と 思われる ${ }^{166} . \mathrm{Na}^{+}$依存性の共輸送体もわずか同時に発

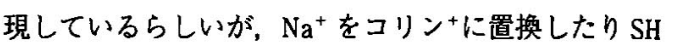
修飾試薬を前もって加えておくと, 促通搪散輸送体の 応答だけを測定できる ${ }^{\mid 6 !}$.

\section{5. 利点と問題点}

輸送系は，小腸や腎臓から調製した膜ベシクルと放 射標識した物質とを用いて，測定されている．この方 法は流入を直接測定できるという点では優れている. 例えば，Glc の促通拡散のように電荷移動がない輸送 系は，電気的応答は測定できない.しかし膜ベシクル は体積が小さいため，すぐに飽和し，短時間での流入

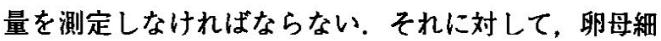
胞は直径 $1 \mathrm{~mm}$ 以上あり，応答が長時間持続する ${ }^{181}$. ま た流入量の測定だけでなく，電気生理学的測定も容易 で，同じ細胞を用いて繰り返し長時間に渡って測定で きる.ただ卵母細胞自体が $\mathrm{Na}^{+}$依存性の輸送系を 持っており，mRNAを注入しなくても応答が現われ る場合があるので，注意する必要がある゙!．卵母細胞 の発現系は，翰送系のクローニングに役立つし，さら に部位特異的変異などと組みあわせると，輸送系の分 子レベルでの機構解明に大变役立つものと思われる.

この研究は, 山口大学理学部生, 石井尚, 阿南真, 富田和郎, 杉尾滋宣氏との協同で行なったものです.

\section{女 献}

1) Gurdon, J. B., Lane, C. D. and Woodland, H. R. (1971) Nature, 233, 177- 182.

2) Barnard, E. A., Miledi, R. and Sumikawa, K. (1982) Proc. $R$. Soc. London B 215, 241-246.

3) 杉山博之（1988）神経情報伝達分子(葛西, 吉岡, 木島, 塚原, 栗原, 鈴木紡) 19-25, 培風館, 東京.

4) Gundersen, C. B., Milede, R. and Parker, I. (1984) Nature, 308, 421-424.

5) Aoshima, H., Anan, M., Ishii, H., Iio, H. and Kobayashi, S. (1987) Biochemistry, 26, 4811 4816.

6) Sugiyama, H., Ito, I. and Hirono, C. (1987) Nature, 325, 531- 533.

7) Masu, Y., Nakayama, K., Tamaki, H., Harada, Y., Kuno, M. and Nakanishi, S. (1987) Nature, 329, 
836-838.

8) Mishina, M., Tonimatsu, T., Imoto, K., Tanaka, K., Fujita, Y., Fukuda, K., Kurasaki, M., Takahashi, H., Morimoto, Y., Hirose, T., Inayama, S., Takahashi, H., Kuno, M. and Numa, S. (1985) Nature, 313, $364-$ 369.

9)星 猛 (1987) 膜輸送の生理学 (星, 香川編) 106-119, 医学書院, 東京.

10) Morgan, M., Hanke, P., Gryorczyk, R., Tintschl, A., Fasol, H. and Passow, H. (1985) EMBO J., 4, 19271931.

11) Kobayashi, S. and Aoshima, H. (1986) Dev. Brain Res., 24, 211-216.

12) Aoshima, H., Iio, H., Anan, M., Ishii, H. and
Kobayashi, S. (1987) Mol. Brain Res., 2, 15-20.

13) Aoshima, H., Ishii, H. and Anan, M. (1987) Mol. Brain Res., 2, 263-267.

14) Hediger, M. A., Ikeda, T. S., Coady, M., Gundersen, C. B. and Wright, E. M. (1987) Proc. Natl. Acad. Sci. USA, 84, 2634- 2637.

15) Hediger, M. A., Coady, M. J., Ikeda, T. S. and Wright, E. M. (1987) Nature, 330, 379-381.

16) Aoshima, H., Tomita, K. and Sugio, S. (1988) Arch. Biochem. Biophys., 265, 73-81.

17) Jung, D., Schwarz, W. and Passow, H. (1984) J. Membr. Biol., 73-81.

18) Aoshima, H., Iio, H. and Kobayashi, S. (1986) Anal. Biochem., 156, 257-262.

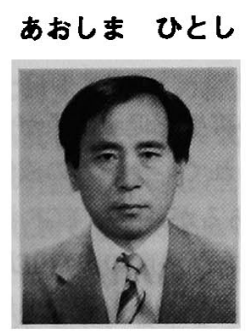

1974年10月京都大学大学院理学研究科化学専攻博士課程を中退し て, 山口大学教養部へ. 現在助教授. 趣味は, テニス, 本の乱読, 木や花を育てること. 酵反応機構の研究を行っていたが, 1978年 から 2 年間コーネル大学へス研究室にて, 神経伝達物質受容体の作 用機構の研究へ. 最近は, アフリカッメガエル卵母細胞の翻訳系を 利用した研究を行っている. 本年 7 月からへス研究室再訪問中.

連絡先 テ753 山口市吉田1677の1 山口大学教養部

○ 0839-22-6111 内線585

出張先 c/o Prof. G. P. Hess, Section of Biochemistry, Molecular and Cell Biology, Cornell University, 270 clark Hall, Ithaca, New York 14853-2501 U.S.A.

吉岡書店出版事業部より

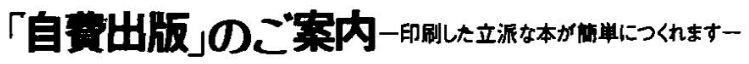

記念論文集/予稿集/リプリント/旅行記/回顧録／詩歌句集

遗稿・追悼集/画・写真集 / その他

字くばり・印刷・製本・用紙・装丁・あらゆるご相談に応じます 案内書お送りします

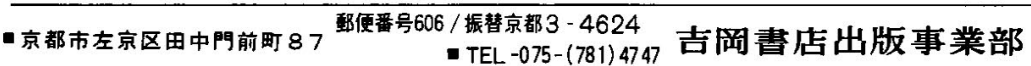

